\title{
A Contrastive Analysis of the Category of Number in English and Albanian Nominal System
}

\author{
Agnesa Canta, PhD Candidate \\ University of Tirana, Albania \& University of Prishtina, Kosovo
}

doi: 10.19044/esj.2016.v12n32p33 URL:http://dx.doi.org/10.19044/esj.2016.v12n32p33

\begin{abstract}
English and Albanian as members of the Indo-European trunk of languages undoubtedly share certain characteristics, common for all members of this family of languages, but as two structurally different languages, they also show significant differences. The main aim of this paper is to highlight not only some of the differences, but also similarities in regard to the grammatical category of number in English and Albanian nominal system.

The paper is based on various English and Albanian grammar books, written by prominent authors, which provide an abundance of data examined through the contrastive method. The results indicate that nouns in these two languages show differences which concern several aspects of the grammatical category of number. Some of these differences concern the way these two languages treat nouns in the singular and plural number, the ways of forming the plural number, and their usage with articles and numerals. One essential difference, however, concerns the collective and compound nouns which show an almost complete discrepancy in these two languages due to the ways they write these nouns, and the ways these nouns function in these languages. Nevertheless, in spite of the differences, there are also some similarities that concern mainly the ways of forming the plural number, but also the group of nouns used only in the singular called "singularia tantum", and those used only in the plural "pluralia tantum".
\end{abstract}

Keywords: Nouns, category, number, differences, similarities

\section{Introduction}

The category of number is a grammatical category which English, Albanian and many other modern languages share. Nevertheless, while in Albanian, the issue of grammatical categories, including the category of number, has never been a matter of dispute, this is not the case with grammatical categories of nouns in English which have been the cause of 
debate among different researchers, both native and foreign ones. However, despite their reserves concerning other grammatical categories, they all acknowledge number as a grammatical category of nouns in English. Furthermore, according to Trask, L.R. (2007), the category of number is the only grammatical category that affects English nouns.

Nouns as the largest word class in both, English and Albanian, have two numbers: 1) the singular number, and 2) the plural number.

Number as a grammatical category of nouns in English and Albanian, and not only, indicates the difference between the singular and plural, namely, the number of people, animals, things, concepts, idea, etc. The singular number always refers to one person, one animal, one thing, one concept, one idea, etc., and it may be preceded by the numeral one, whereas the plural number has two references. It may refer to:

a) More than one person, animal, thing, concept, idea, etc., and this means that the noun may be preceded by all numerals, except the numeral one.

b) Several or more people, animals, things, concepts, ideas, etc., and this means that the noun in plural may be used with or without a numeral. However, even when used without a numeral, the plurality is implied.

The first part of this paper examines precisely the way English and Albanian treat their nouns in the singular and plural, whether each of these languages allows articles with nouns in the singular and plural, the kinds of numerals that may be used with nouns in the singular and plural, and exceptions to the rules concerning the usage of articles and numerals with nouns in both numbers, whereas the second part focuses mainly on the ways they form the plural number emphasizing the differences and similarities.

\section{The Category of Number in English and Albanian Nominal System}

The grammatical category of number is one of the categories that English and Albanian have in common. But, English as an analytic language and Albanian as an inflectional language, being structurally different, show many differences and also similarities in the way they treat nouns in the singular, and the way they form the plural. In English, nouns in the singular number are always used either with the numeral one or with an article, the indefinite article a/an which is semantically equal to the numeral one, and the definite article the:

$$
\begin{gathered}
\text { one/a student or one/an apple } \\
\text { the student }
\end{gathered}
$$

In English, nouns in the singular number may not be used without an article or without the numeral one. Forms such as student or apple, used without the above mentioned functional words, are grammatically unacceptable. Proper nouns and uncountable nouns, such as Tom, William, 
Jane, James, London, Washington, love, courage, peace, water, bread, sugar, milk, furniture, etc., are, of course, an exception to the rule. Proper nouns do not take the numeral one nor the indefinite article $a / a n$, but they can be used with the definite article the. From this group, we can distinguish personal names which make use of the stressed definite article the /ði:/ which, according to Huddleston \& Pullum (2002), is highly unusual. In this form, the definite article the [ði:] has three functions:

1. to verify the identity of the person we are addressing to - Are you the Mrs. Carlyle? (we recognize the person, but we are not quite sure of his/her identity, and expect a confirmation)

2. to distinguish two people with the same name from one another I need to see the Mrs. Harrison who has organized this event.

3. to express surprise at someone's behaviour - You are not the Rebecca I know! (I know who you are, but you are not acting accordingly) In this last function the [ði:] is especially used in American English.

Uncountable nouns are not used with the numeral one, nor with the indefinite article $a / a n$, but they use the unstressed definite article the:

There is no time for regret. (an uncountable noun used without the numeral one or articles)

This is the time to act and end the misery. (an uncountable noun used with the article the)

Unlike English, in Albanian, nouns do not take articles. Singular nouns can be used with or without the numeral one, but when used with the numeral, they emphasize the number of animates, things, concepts designated by those nouns, and not solely the fact that they are singular nouns, that is, the category of number. E.g.

një student/e (one student) student/e (a student) studenti/ja (the student)

një klasë (one class) klasë (a class) klasa (the class)

një libër (one book) libër (a book) libri (the book)

një mollë (one apple) mollë (an apple) molla (the apple)

As seen in these examples, unlike English, the defineteness and the indefiniteness of singular nouns in Albanian is expressed by inflections and not by articles.

When we use the expressions një student (one student) or nje libër (one book), we refer directly to the number of students or the number of apples, thus, in the first place, we highlight the fact that there is only one student or one apple, and in the second place comes the sematic implication of the noun student as member of a group of people, and the noun apple as a kind of fruit, unlike student/e (a student) and studenti/ja (the student), or mollë (an apple) and molla (the apple, which in the first place put emphasis on the group of people, respectively on the kind of fruit to which student, 
respectively apple belongs to, and only in the second place emphasize their number which is obviously implied by their form.

Both English and Albanian proper nouns and uncountable nouns are used only in the singular number, and they do not ordinarily take numerals, but there are exceptions to this rule in both languages. In English, surnames as proper nouns take the plural form when referring to the people in the family with the same name (Greenbaum \& Nelson, 2009, p.33):

The Hiltons have built hotels all ever the world.

I have known the Clarks since 2001.

In Albanian, proper nouns are used in the plural only in special cases to identify by surname a number of people who carry that surname (Newmark, Hubbard \& Prifti, 1982, p. 127):

Jasharajt janë familje e shquar nga Kosova. (The Jasharajs are a distinguished family from Kosova)

Lekajt njihen si njerëz të urte e të kulturuar. (The Lekajs are known as wise and cultured people)

As seen in these examples, in English, unlike Albanian, surnames as proper nouns, used in the plural, always take the definite article the.

Proper nouns as personal names can be used with cardinal and ordinal numbers in both English and Albanian:

a) with cardinal numbers - to refer to one, two, or more people, all at the same time, f.i.

I met three Kellys in my cousin's wedding.

Unё u njoftova me tri Arta nё dasmën e kushëririt tim. (I was introduced to three Artas in my coursin's wedding.)

Used with cardinal numbers, nouns in Albanian retain their singular form, whereas those in English change their form from singular to plural.

b) with ordinal numbers - to refer to one, two, or more people with the same name, one by one.

You are the third John I have met today.

I have met today.)

Ti je Genci i tretë që kam takuar sot. (You are the third Genci

As these examples indicate, when personal names as proper nouns are used with ordinal numbers, they retain the singular form, but in English, they also take articles.

Proper nouns as names of places can also be used with numerals, but only with cardinal numbers, to refer to two or more places with the same name.

There are two Virginias in the United States of America.

Ne rrethin e Tiranës ka dy Selita: Selita e Madhe dhe Selita e Vogël.

"In the district of Tiranë there are two Selitas: Big Selita and little Selita” (Newmark, et al., 1982, p.127) 
In Albanian, the noun retains its singular form, whereas in English, it changes from singular to plural.

In English, such names are sometimes, albeit rather rarely, used with both, a numeral and the definite article, and sometimes only with the article.

They have faced a range of difficulties in the two Virginias.

The Virginias are the two states of the federal country called the United States of America.

In Albanian, such names take the plural form only when used without a numeral.

Selitat janë dy fshatra të rrethit të Tiranës. (Selitas are two villages in the Tirana District.)

These last two examples indicate that in both languages, English and Albanian, proper nouns referring to places with the same name have plural forms, the difference being that in English they must take the definite article, too.

Concerning the ways of forming the plural of nouns, despite the differences, English and Albanian also show some similarities:

\section{Both languages have nouns with the same stem in singular and plural}

A group of nouns in English and Albanian have the same stem in the singular and plural number. In English, these nouns are said to have "zero plural”, and they are a small group of nouns that name mainly animals, birds, fish, names of nationalities, the noun craft, compound nouns formed by craft as a second element, and several nouns indicating number and measurement (Karlovcan, 1989):

a) Names of some animals, birds, fish - sheep-sheep (dele-dele), deer-deer (dre-drerë), snipe-snipe (shapkë-shapka), grouse-grouse (thëllëzëthëllëza), swine-swine (derr-derra), fish-fish (peshk-peshq), trout-trout (troftë-trofta), etc. From their equivalent nouns in brackets, we can see that in Albanian, only the noun dele has the same stem in the singular and plural number.

b) Names of several nationalities - Japanese (japonezë), Chinese (kinezë), Portuguese (portugezë), Vietnamese (vietnamezë), Swiss (zviceranë).

In Albanian, names of these nationalities have the same stem in the singular and plural number, but only when they are used as indefinite nouns. Nonetheless, it should be emphasized that these nouns in English have the same stem in the singular and plural only because they are used with determiners, respectively the definite article the, otherwise, forms without determiners are grammatically unacceptable. E.g.

The Swiss are known for their famous watches.

Swiss are known for their famous watches. * 
c) craft - aircraft (aeroplan), spacecraft (anije kozmike), hovercraft (anije) The noun craft is incuded in this group of nouns only when it is used to refer to a boat, otherwise, when it refers to a job, skill, or activity, it forms the plural by adding the regular plural inflectional suffix -s. This group also includes nouns such as counsel and offspring (Bache \& Davidsen Nielsen, 1997, p.393).

In Albanian, except the noun airplane, other nouns have the same stem in the singular and plural.

d) Nouns indicating number and measurement - dozen, hundred, thousand, score, brace, gross, horsepower, etc. These nouns, in English and Albanian both, have the same stem in the singular and plural only when they are preceded by a numeral:

two dozen roses (njëzet e katër trëndafila) dozens of roses (dhjetëra trëndafila)

three hundred students (treqind studentë) hundreds of students (qindra studentë)

five thousand inhabitants (pesë mijë banorë) thousands of inhabitants (mijëra banorë)

two thousand horsepower (dy mijë kuaj-fuqi) thousands of horsepower (mijëra kuaj-fuqi)

According to Greenbaum (1996, p.102), nouns such as foot (length unit), pound (unit of weight or of British currency), and stone (British weight unit) optionally take zero plurals: six foot two, twenty pound, fifteen stone, which means that they can be used in two forms: six foot or six feet, twenty pound or twenty pounds, ten stone or ten stones.

In Albanian, there is a considerable number of nouns that have the same stem in the singular and plural number. These are the feminine nouns that end in unstressed $-\boldsymbol{e}$ and $-\boldsymbol{o}$, feminine nouns that end in stressed vowels $\boldsymbol{a}, \boldsymbol{- e},-\ddot{\boldsymbol{e}}, \boldsymbol{- i}, \boldsymbol{- o}$, and $-\boldsymbol{u}$, masculine nouns that are formed mainly with the

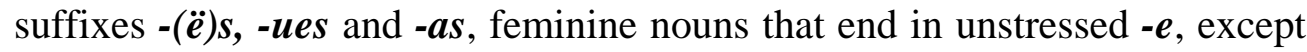
those that in the plural take the inflectional suffx - $\boldsymbol{a}$, as well as a few other nouns (Agalliu et al., 2002, p.96-97). E.g.

Feminine nouns:

Masculine nouns:

shoqe-shoqe (friend-friends)

vello- vello (veil-veils)

nxёnёs-nxёnёs (pupil-pupils)

shtëpi-shtëpi (house-houses)

kope-kope (herd-herds)

tabu-tabu (taboo-taboos)

kala-kala (fortress-fortresses)

fjalë-fjalë (word-words)

Masculine nouns:
nхёnёs-nxënёs (pupil-pupils)
mësues-mësues(teacher-teachers)
tiranas-tiranas (Tiranan-Tiranans)
prishtinas-prishtinas (Pristinan-Pristinans)
muze-muze (museum-museums)
muaj-muaj (month-months)
sy-sy (eye-eyes), etc.

As these examples indicate, all their English counterparts in brackets have regular plural forms. But, unlike English, in Albanian, these nouns have 
the same form in the singular and plural regardless of the cardinal numbers that might be used with them only when they are used as indefinite nouns. If used as definite nouns, they take the regular plural endings. E.g.

shoqe-shoqet, shtëpi-shtëpitë, nхёnёs- nxёnёsit, muaj-muajt, sy-sytë, etc.

\section{Formation of the plural number with inflectional suffixes}

One similarity between English and Albanian concerns the formation of the noun plural with inflectional suffixes. Most of the nouns in English form the plural number by adding the inflectional suffix -es/s. Such nouns are called regular nouns, unlike other nouns that do not take this inflectional suffix and are called irregular nouns. Albanian, on the other hand, as a highly inflectional language makes use of many different inflectional suffixes to form the noun plural, and the process of forming the plural in this way depends on the noun gender.

a) Thus, feminine nouns form the plural by adding the inflectional suffix -a, f.i. vajzë-vajza (girl-girls), vegël-vegla (tool-tools), flutur-flutura (butterfly-butterflies), mjegull-mjegulla (fog-fog), motër-motra (sistersisters), vepër-vepra (work-works), etc. Most of these nouns that form the plural with -a are regular nouns in English, forming their plural with the suffix -es/s. These examples show that the English counterparts in brackets are all regular nouns ending in $\mathbf{s}$, with the exception of the noun fog which as an uncountable noun does not have a plural form.

\section{nj, -enj,}

b) Masculine nouns form their plural with these suffixes: $-\boldsymbol{a}, \boldsymbol{- e},-\ddot{\boldsymbol{e}},-$

-inj, -ër, and -ra (Agalliu, et al., 2002), f.i. trup-trupa (body-bodies), synim- synime (aim-aims), shkrimtar-shkrimtarë (writer-writers), heroheronj (hero-heroes), lumë-lumenj (river-rivers), shkëmb-shkëmbinj (rockrocks), prind-prindër (parent-parents), mall-mallra (goods-goods), etc. In English, most of these nouns have regular plural forms. Examples indicate that the only noun that makes an exception is the uncountable noun goods.

However, according to Veselaj (2015), there is another inflectional suffix used to form the plural of masculine nouns in Albanian, namely, $-\boldsymbol{i}$, which albeit considered an extinct suffix, it can still be found nowadays in the plural forms such as bujk-bujqi (farmer-farmers), krushk-krushqi (in-lawin,-laws) ujk-ujqi (wolf-wolves), peshk-peshkqi (fish-fish), etc., used in the local dialects of Albanian. Veselaj (2015) claims that Albanian researchers such as: Halimi, Pajaziti, Zymberaj, and others share his opinion. Indeed, these plural forms are quite common in the Gheg Dialect spoken in Kosovo.

c) Neuter nouns form their plural with the suffix - $\boldsymbol{a}$ (Agalliu, et al., 2002), e.g. të qeshur-it-të qeshura (laugh-laughs), të bërtitur-it-të bërtitura 
(scream-screams), të qarë-t-të qara (cry-cries), etc. In English, these nouns take the regular plural suffix -s/-es.

Except the regular nouns that form the plural by adding the suffix $-\mathbf{s}$ es, there are also some irregular nouns in English which also make use of inflectional suffixes to form their plural forms. These are the inflectional suffixes -ren and -en, and they are used to form these nouns:

\section{child-children ox-oxen brother-brothren}

Brethren is the form used only to refer to members of a religious community, otherwise the regular plural form brother is used. $O x$, on the other hand, in American English is used in two variants: regular oxes and the unchanged form of ox (Greenbaum, 1996, p.102).

The fact that the function of the inflectional suffix -s/-es in forming the plural of nouns in English is realised by a larger number of inflectional suffixes like $-\boldsymbol{a},-\boldsymbol{e},-\ddot{\boldsymbol{e}},-\boldsymbol{n j}$, - $\boldsymbol{e n j}, \mathbf{i n j},-\ddot{\boldsymbol{e}} \boldsymbol{r}$, and -ra in forming the plural in Albanian, indicates that Albanian as an inflectional language makes use of a larger number of inflectional suffixes, mostly, because in Albanian they determine the syntactic functions between the words in the sentence, and this way they also determine their sematic function, unlike English that has a limited number of inflectional suffixes, because they also have a limited role in the syntactic functions of the words within the sentence, a role that is mainly realised by word order.

\section{Formation of the plural by a sound change}

Nouns can also form their plural in both languages, English and Albanian, by a sound change, respectively, a vowel change and a consonant change. However, they constitute a rather small group. These are the nouns that form the plural only by a vowel change:

In English: man-men (burrë-grua), woman-women (grua-gratë), footfeet (këmbë-këmbë), tooth-teeth (dhëmbë-dhëmbë), goose-geese (patë-pata).

In Albanian: kulaç-kuleç (scone-scones), dash-desh (ram-rams), cjap-cjep (billy goat-billy goats), rreth-rrathë (circle-circles), natë-net (night-nights), thasë-thes (sack-sacks) (Agalliu, et al., p.103).

The common feature of these nouns is that, in both languages, they belong to the group of old nouns dating from Old English, respectively Old Albanian.

Unlike Albanian which forms the plural of several nouns by a consonant change, f.i. mik-miq (friend-friends), zog-zogj (bir-birds), popullpopuj (people-peoples), bir-bij (son-sons), etc., in English, there are no nouns that form the plural by a consonant change.

Nouns can also form the plural by changing the vowels and consonants both. In Albanian, we can find many nouns that form the plural this way, e.g. mashkull-meshkuj (man-men), plak-pleq (old man-old men), 
hamaj-hamej (loader-loaders), bakall-bakej (grocer-grocers), whereas in English, there are only two such nouns: mouse-mice (mi-minj), dhe louselice (morr-morra), although according to Collinson Nesfield (2014), the noun dormouse - dormice (gjer-gjera) belongs to this group, too.

There are also a few nouns in English that have two plural forms, the regular noun plural form and the plural form with a sound change, depending on the context in which the noun is used. For example, when the noun penny is used as a British monetary unit, it has pennies as the plural form, whereas when used as "small change", it has pence as its plural form (Bache \& Davidsen Nielsen, 1997). According to Rumjanceva \& Kalniòa (2003), this group of nouns includes: brother (brothers- brethren), cloth (cloths-clothes) and penny (pennies-pence).

\section{Formation of the plural with suffixes and a sound change}

Formation of the noun plural by a sound change combined with suffixes is quite common in Albanian, f.i. varg-vargje (verse-verses), pellgpellgje (pond-ponds), park-parqe (park-parks), cak-caqe (target-targets), lakleqe (trap-traps), breg-brigje (hill-hills), shteg-shtigje (path-paths), etc., whereas in English, there are only several nouns that form the plural this way: dwarf-dwarves, calf-calves, elf-elves, half-halves, hoof-hooves, knifeknives, leaf-leaves, life-lives, loaf-loaves, roof-rooves, self-selves, sheafsheaves, shelf-shelves, thief-thieves, wharf-wharves, wife-wives, wolf-wolves, Nowadays, nouns such as dwarf, hoof, roof, and wharf do not commonly apply the sound change in the plural number, using only the plural suffix $-\boldsymbol{s}$ instead, even though Kabashi (2000) claims that both forms are possible.

\section{Formation of the plural of nouns of foreign origin}

As one of the languages with a distinct flexibility in regard to the borrowings, one of the special features of English is the preservation of original forms of the borrowed nouns, even though in the recent years, there has been a tendency, especially in American English, to replace the foreign inflectional suffixes with the native one, namely $-\boldsymbol{e s} / \mathbf{s}$, but this tendency has also tackled the nouns with frequent usage, and not only those that are part of the scientific terminology.

a) Nouns of Latin origin:

$\begin{array}{cc}\text { Singular } & \text { Plural } \\ \text { apparatus (aparat) } & \text { aparati (aparate) } \\ \text { terminus (termin) } & \text { termini (termine) } \\ \text { alga (algë) } & \text { algae (alga) } \\ \text { formula (formulë) } & \text { formulae (formula) } \\ \text { datum (e dhënë) } & \text { data (të dhëna) } \\ \text { medium (mjet) } & \text { media (mjete) }\end{array}$


appendix (shtojcë)

matrix (matricë)

b) Nouns of Greek origin:

Singular

hypothesis (hipotezë)

analysis (analize)

thesis (teze)

basis (baze)

crisis (krize)

automaton (automat)

phenomenon (fenomen) apendices (shtojca)

matrices (matrica), etc.

Plural

hypotheses (hipoteza)

analyses (analiza)

theses (teza)

bases (baza)

crises (kriza)

automata (automate)

phenomena (fenomene), etc.

Some of these nouns of Latin and Greek origin can be found in two forms, their original plural form, or their anglicised plural form. E.g.

aquarium - aquaria - aquariums (akuarium-akuariume)

memorandum - memoranda - memorandums (memorandummemorandume)

symposium - symposia - symposiums (simpozium-simpoziume) stadium - stadia - stadiums (shkallë- shkallë) index - indices - indexes (indeks-indeksa)

matrix - matrices - matrixes (matrice-matrica)

formula - formulae - formulas (formulë-formula)

phenomenon - phenomena - phenomenons (fenomen-fenomene)

Unlike English, Albanian does not preserve the original plural forms. When a noun is included in the Albanian vocabulary, it undergoes certain grammatical rules applied in forming the plural of all Albanian nouns. From the examples above, we can see that while in English, nouns retain the original plural form, in Albanian they take the relevant Albanian inflectional suffixes used for forming the plural of nouns.

Nonetheless, English has not been immune to naturalisation, thus, according to Baskervill \& Sewell (2014) there are several nouns of Latin and Greek origin that have already completely lost their original plural forms, and most of these nouns are not part of the scientific terminology: bandits (banditë), cherubs (kerubinë), dogmas (dogma), enigmas (enigma), formulas (formula), encomiums (lavdata), herbariums (herbariume), focuses (fokuse), geniuses (gjeni), seraphs (serafinë), indexes (indekse), apexes (maja). Furthermore, there are several nouns of foreign origin that end in -a, a foreign inflectional suffix indicating the plural, such as agenda and insignia that are used as singular nouns,whereas media, criteria, phenomena, strata are normally treated as plural nouns, with the exception of media in the sense "mass media" which is often treated as singular (Greenbaum, 1996, p.103). 
However, according to Huddleston \& Pullum (2002, p.348), nouns such as bacteria criteria, insignia, media and phenomena are treated as singular nouns with regular plural counterparts bacterias, criterias, insignias, medias, and phenomenas, but only “insignias' has gained any significant degree of acceptance, and that in AmE rather than BrE, whereas others are still regarded as non-standard forms.

In English, nouns of French and Italian origin are usually found in two plural forms, with their original plural suffixes and the regular English plural suffix. In French, the plural number is formed with the suffix -eu/-eau pronounced as $\mathbf{- z}$ in English (Kabashi, 2000, p.180), e.g. bureau-bureaux (zyrë-zyra, byro-byro), chateau-chateaux (kështjellë-kështjella), tableautableaux (pikturë-piktura, tabllo-tabllo), plateau-plateaux (plato-plato), portmanteau-portmanteaux (valigje-valigje), etc. But Bache \& Nielsen (1997, p.393) claim that these nouns are also used as regular plural nouns taking the inflectional suffix -s-/es, e.g. bureau-bureaus, chateau-chateaus, portmanteau-portmanteaus, etc. As seen in the examples above, some of their Albanian counterparts in the brackets also show a tendency of preserving the original form in translation. Furthermore, they show the same form for both the singular and the plural number. Thus, the noun tableau in Albanian has two translations: pikturë and tabllo, the latter used mainly in literature and fine arts. When translated as pikturë, it has a different plural form piktura, whereas, when translated as tabllo, it doesn't change the form, so the singular and the plural form are the same (tabllo-tabllo). The same rule applies to plateau (plato) and bureau (byro), too.

Nouns of Italian origin are mainly nouns that concern the music, and they keep both, their original plural suffix and the regular plural English, e.g. tempo - tempi - tempos (tempo-tempo), libretto - libretti - librettos (libreto-

libreto), virtuoso - vistuosi - virtuosos (virtuoz-virtuozë), etc.

In Albanian, nouns of French and Italian origin, referred to as "neolatin" nouns, like the rest of the borrowed nouns, form their plural by adding the regular Albanian plural suffixes, e.g. divergjencë-divergjenca (divergencies), definicion-definicione (definitions), divorc-divorce (divorces), circuit-cirkuite (circuits), ekuiliber-ekuilibre (equilibriums), eveniment-evenimente (events), firmë-firma (firms), iniciativë-iniciativa (initiatives), konkluzion-konkluzione (conclusions), presion-presione (pressures), etc.

Unlike English, Albanian borrowed form Turkish, too, considering the circumstances of bringing these two languages together, but all those nouns have been naturalised in the sense that they all take Albanian plural suffixes. E.g. komshi - komshinj (neighbours), alet - alete (tools), bina binate (buildings), etc. 
In the recent years, Albanian has borrowed extensively from English, due to several reasons. Primarily, due to the influence that English as a global language, largely thanks to the modern technology, excerts over other languages in the world, especially smaller languages such as Albanian, and secondly, due to the impact of the international organisations situated in Kosovo after the war of 1999. The internationals who have settled in Kosovo after the war have undoubtedly contributed quite a lot to the increased number of English words, mainly nouns, used in Albanian. Here are some examples of English nouns borrowed by Albanian:

$$
\text { Singular Plural }
$$

Alternative noun in

Albanian

$$
\text { aprovim-aprovime (approval-approvals) }
$$

bord-borde (board-boards)

-miratim

determinim-determinimet (determination - determinations) -këshill

implementim-implementime (implementation-implementations) -zbatim, kooperim- kooperime (cooperation-cooperations)

- bashkëpunim staf-stafe (staff-staffs)

- personel, etc.

However, when there are nouns in Albanian with the same meaning as the nouns borrowed from English, as it is shown above, it is not recommended to use the borrowed ones, regardless of their spread and impact. But, when it comes to the things, activities, phenomena that Albanian does not have the linguistic means to cover, such as computer (kompjuter), printer (printer), monitor (monitor) software (softuer), hardware (harduer), bypass (bajpas), business (biznes), college (kolegj), corruption (korrupsion), transition (tranzicion), consensus (konsensus), tolerance (tolereancë), inflation (inflacion), transparency (transparencë), import (importi), export (eksporti), etc. , it is only natural to borrow from English as a global language. Most of these nouns are now part of the standard Albanian vocabulary. They all take Albanian plural suffixes, except the uncountable nouns like corruption (korrupsion), inflation (inflacion), transparency (transparencë), tolerance (tolerancë) software (softuer), hardware (harduer), etc.

\section{Formation of the plural of compound nouns}

English and Albanian show substantial differences in regard to compound nouns, and these differences do not only concern the ways they form the plural number, but also their productivity of the compound nouns, and also the ways in which they are written in the respective languages. Due to many reasons which will not be dealt with in this paper, English is much more productive than Albanian when it comes to compounds, which has resulted in a large number of compound nouns in English, and a very limited number of compound nouns in Albanian. Çabej, one of the most outstanding 
Albanian scholars, claimed that "in Albanian, compounds are relatively scarce" (Çabej, 1976, p.101). This view is shared by many other researchers of Albanian, such as Dozon, Weingand, etc., (Kostallari, A., 1972), but the number of compound nouns in Albanian is slowly increasing, even though it is still not as significant as that of English compound nouns. However, in regard to the ways they form the plural number, despite the differences, these two languages show some similarities as well.

a) Most of compound nouns in English and Albanian form their plural number by adding the regular plural English suffix -s/es, and the respective Albanian plural suffixes to the second element. E.g.

airplane - airplanes

backstage - backstages

bodyguard - bodyguards

crossroad - crossroads

crossword - crosswords

photoreporter - photoreporters

prime minister - prime ministers

masterpiece - masterpieces

waterfall - waterfalls

weekend - weekends aeroplan - aeroplanë

prapaskenë - prapaskena

truprojë - truproje

udhëkryq - udhëkryqe

fjalëkryq - fjalëkryq

fotoreporter - fotoreportere

kryeministër - kryeministra

kryevepër - kryevepra

ujëvarë - ujëvara

fundjavë - fundjava

fjalëformim - fjalëformime

word-formation - word-formations

These examples show that compound nouns in English and their Albanian counterparts with the same meaning form the plural in the same way. But this is not the case with all compound nouns in these languages.

Several compound nouns, that have an adverb as a second element, form the plural by adding the regular plural suffix to the second element. E.g. close-up - close-ups, take-over - take-overs, stand-in - stand-ins (Greenbaum, 1996, p.105). There are no such compound nouns in Albanian.

b) A small number of compound nouns in English form their plural by adding the regular plural suffix to the first element. This occurs:

-If the compound noun has a prepositional phrase, or simply a preposition as the second element (Greenbaum, 1996, p.105), e.g.

mother-in-law - mothers-in-law, brother-in-law - brothers-in-law editor-in-chief - editors-in-chief, passer-by - passers-by

looker-on - lookers-on, listener-in - listeners-in, etc.

Only editor-in-chief - kryeredaktor is a compound noun in Albanian, but it forms the plural by adding the plural suffix to the second element, therefore, we have: kryeredaktor - kryeredaktorë.

-If the compound noun has an adjective as the second element, it can take regular plural suffix in the first or second element. (Greenbaum, 1996, p.105) These are mainly nouns of French origin. E.g. court martial / courts martial or court martials 
attorney general / attorneys general or attorney generals poet laureate / poets laureate or poet laureates

c) Compound nouns in English and Albanian can form the plural by a sound change, but their number is very small. In English, these are the nouns whose second element is man or woman. E.g.

$\begin{array}{cr}\text { Englishman - Englishmen } & \text { Englishwoman - Englishwomen } \\ \text { nobleman - noblemen } & \text { noblewoman - noblewomen } \\ \text { businessman - businessmen } & \text { businesswoman - businesswomen } \\ \text { spokesman - spokesmen } & \text { spokeswoman - spokeswomen } \\ \text { fisherman - fishermen } & \text { fireman - firemen, etc. }\end{array}$

In Albanian, this group comprises only few compound nouns such as: rrokaqiell - rrokaqiej (skyscraper - skyscrapers) luledielli - lulediej (sunflower-sunflowers)

d) When compound nouns have man or woman as the first element, both elements in the compound noun take the plural form. E.g.

$\begin{array}{cc}\text { woman journalist - women journalist } & \text { man journalist - men journalists } \\ \text { woman doctor - women doctors } & \text { man doctor - men doctors } \\ \text { woman driver - wome drivers } & \text { man driver - men drivers }\end{array}$

Woman may be replaced by lady, which is not pluralized, f. i. lady friend - lady friends, lady doctor - lady-doctors, landlady - landladies, etc. (Kabashi, 2000, p.182).

e) Unlike English, Albanian has several compound nouns that have the same stem in the singular and plural number. E.g.

$\begin{array}{lc}\text { spokesman - spokesmen } & \text { zëdhënës - zëdhënës } \\ \text { spokeswoman - spokeswomen } & \text { zëdhënëse - zëdhënëse } \\ \text { fireman - firemen } & \text { zjarrfikës - zjarrfikës } \\ \text { birthday - birthdays } & \text { ditëlindje-ditëlindje } \\ \text { hometown - hometowns } & \text { vendlindje - vendlindje } \\ \text { viewpoint - viewpoints } & \text { pikëpamje - pikëpamje }\end{array}$

Examples indicate that none of their English counterparts has the same stem, because in English compound nouns usually take plural forms.

English and Albanian show essential differences in the way they write the compound nouns. In Albanian, as seen in the examples above, compound nouns are usually written as one word. They may not be written as two words, and they cannot be hyphenated either, with the exception of a few nouns: qytet-muze (city-museum), shtëpi-muze (house-museum), vagonrestaurant (wagon-restaurant), qen-ujk (dog-wolf), vajtje-ardhje (departurearrival), etc., and a few geographical names like Nikaj-Mertur, Fier-Shegan, Fushë-Arrëz, Zall-Dajt, etc. (Agalliu, et al. 2002)

In English, on the other hand, compound nouns may be written in three ways: as one word (hometown), hyphenated (frying-pan), and as two words (high school), although there are no strict rules that would help us 
choose the best option. Hyphenated forms are more frequent in British English, while unhyphenated forms are more frequent in American English.

\section{Formation of the plural of nouns with titles}

English and Albanian show essential differences in the ways they treat their nouns with titles. Thus, in Modern English nouns with titles form their plural by adding the regular plural suffix to the proper noun. E.g.

Mrs. Carrington - the Mrs.Carringtons, Mr. Clark - Mr.Clarks, Miss Grey - the Miss Greys, Professor Sullivans, Doctor Madisons, etc.

In very formal style the title is pluralised (Kabashi, 2000, p.183). E.g. the (two) Misses Bronte, the (three) Doctors Swift, the (two)Professors Brown, etc. However, according to Greenbaum \& Quirk (1990), the title may be pluralized when it applies to more than one succeeding name, e.g. Professors Hopkins and Johnson, Doctors Shelby and O'Neill, etc., but this does not apply to titles such as Miss, Mrs. and Mr.

In certain cases, both the title and the noun used take the plural forms, but this occurs only when the title is followed by a common noun. E.g.

Lord Chancelor - Lords Chancelors, Lord Justice - Lords Justices, Lord Commissioner - Lords Commissioners (Kabashi, 2000, p.182)

The rules concerning the plural of nouns with titles are very strict in Albanian, and thus, only the titles take the plural suffixes, and not the nouns they precede.

Z. (Zotëri) Xhuvani - Z. (Zotërinjtë) Xhuvani

- Mr. Xhuvani

Znj. (Zonja) Begolli - Znj. (Zonjat) Begolli

Znjsh. (Zonjusha) Toska - Znjsh. (Zonjushat) Toska

- Mrs. Begolli

- Miss Toska

\section{Nouns used only in the singular number}

Both languages, English and Albanian have nouns that are used only in the singular. A considerable number of these nouns are abstract uncountable nouns, but the group also comprises concrete uncountable nouns, several compound nouns, and mass nouns. A characteristic of these nouns is the fact that some of them end in $-\boldsymbol{s}$, but this $-\boldsymbol{s}$ does not indicate the plural, but it is simply part of these nouns.

a) Abstract uncountable nouns - courage (guxim), health (shëndet), justice (drejtësi), knowledge (dituri), mind (mendje), peace (paqe), pride (krenari), support (përkrahje), wisdom ( mençuri), etc.

Not only English nouns, but also their Albanian counterparts in the brackets are also used in the singular only.

b) Concrete uncountable nouns - furniture (mobilje), money (para), jewelry (stoli), baggage (bagazh), tableware (takëm), etc. 
In Albanian, the noun mobilie (furniture) has the plural form mobiliet, but only when used as a definite noun. Takëm (tableware), on the other hand is a countable noun, therefore, it has the plural form takëme.

c) Mass nouns - water (ujë), milk (qumësht), oil (vaj/naftë), sugar (sheqer), salt (kripë), cheese (djathë), butter (gjalpë), honey (mjaltë), coal (qymyr), sand (rërë), etc. The Albanian nouns in brackets are also used in the singular number only. mumps

d) Names of some illnesses which end in $-\boldsymbol{s}$ - hives (urtikarie),

(shyta), rabies (tërbim), rickets (rakit), shingles (herpes), haemorrhoids (hemorroide), hiccups (lemzë), measles (fruth) (Huddleston \&Pullum, 2002, p.346). These nouns are usually used with a singular verb, except haemorrhoids, hiccups, and measles, which may take a plural verb as well.

In Albanian, nouns tërbim, rakit, herpes, lemzë, and fruth, are used only in the singular and they always take a singular verb, whereas urtikarie, shyta and hemorroide take plural suffixes and they are usually used with a plural verb. There are some other names of illnesses in English and Albanian that are used only in the singular number with a singular verb, too. E.g. cough (kollë), flu (grip), diarrhea (diare), smallpox (li), but there are also some names of illnesses that are always used as singular nouns in English, but in Albanian, they are used only in the plural: fever (ethet), tonsillitis (bajamet/grykët), or in the singular and plural,both: migraine (migrenë).

e) Names of languages and scientific disciplines - Albanian (shqip), English (anglisht), German (gjermanisht), linguistics (gjuhësi), mathematics (matematikë), economics (ekonomi), medicine (mjekësi), etc.

These nouns are also used in the singular number only and with a singular verb in Albanian as well.

f) Names of sports - football (futboll), basketball (basketboll), volleyball (volejboll), tennis (tenis), box (boks), judo (xhudo), swimming (not), etc. In Albanian, they are also used only in the singular number.

g) Names of certain games - billiards (bilardo), cards (letra), dominoes (domino), skittles (birila), etc. , but except the noun letra (cards) which in Albanian is used as a plural noun , other nouns are all used only in the singular.

h) Nouns that indicate directions of the compass - north (very), east (lindje), south (jug), west (perëndim).

i) Nouns that indicate the atmospheric phenomena - snow (borë), frost (acar), ice (akull), hail (breshër), rain (shi), fog (mjegull), dew (vesë), etc. From these nouns, rain and dew, especially in artistic creations, may be used in the plural number: rains and dews. In Albanian, shi and akull may also be used in in the plural number: shira and akuj. 
j) Names of several plants - wheat (grurë), corn (misër), barley (elb), rye (thekër), spinach (spinaq), sorrel (lëpjetë), etc.

Except the Albanian noun misër, which has the plural form misra, but only when it is referred to the plant as food sold in pieces on the streets, other nouns in both languages, have only the singular form.

k) This group of nouns also comprises nouns referred to as verbal nouns or gerunds which, in English, are formed with the inflectional suffix ing: reading (të lexuarit), writing (të shkruarit), listening (të dëgjuarit), speaking (të folurit), etc. In Albanian, they derived from the substantivization of participles (Newmark, et al., 1982), and they are also used only in the singular.

l) A few compound nouns are also used only in the singular in English and Albanian, both: fatherland (atdhe), motherland (mëmëdhe), homeland (atdhe/mëmëdhe)

m) All collective nouns in Albanian are uncountable nouns and therefore, they have only the singular form. In English, only few collective nouns are used only in the singular.

\section{Nouns used only in the plural number}

English and Albanian share a group of nouns that are used only in the plural. A considerably large number of these nouns are the names of things consisting of two parts, or the so-called "Bipartites" (Huddleston \& Pullum, 2002, p. 340).

a) Bipartites comprise:

Clothes: trousers (pantallona), shorts (pantollona të shkurta), jeans (xhinse), tights (geta), bloomers (kilota), pyjamas (pizhama), knickers (mbathje grash), glasses/spectacles (syze), etc.

Tools: scissors (gërshërë), pincers (darë), tongs (mashë), shears (gërshërë të mëdha), binoculars (dylbi), bellows (shakull), tweezers (piskatore), pliers

(pincë), scales (shkallë), etc

In Albanian, there are only four of these nouns that do not belong to the group: mashë, piskatore, pincë, and shakull. They are used only in the singular.

In English and Albanian, "bipartites" are used with numerals only when they are preceded by the word pair (palë), e.g. a pair of trousers (një palë pantollona), a pair of jeans (një palë xhinse), two pairs of pyjamas (dy palë pizhama), etc. As seen in these examples, in English, when these nouns are used with cardinal numbers other than one, even the word pair takes the regular plural ending $-\mathbf{s}$, whereas in Albanian, the word palë retains its singular form, regardless of the numeral. 
b) Members of this group are also the nouns formed from adjectives with articles. English uses the definite article the, whereas Albanian uses the article të and the respective inflectional suffix. E.g. the poor (të varfërit),

the rich (të pasurit), the famous (të famshmit), the sick (të sëmurët), the young (të rinjtë), the elders (të moshuarit), etc.

c) Several proper nouns indicating places - the Alps (Alpet), the Himalayas (Himalajet), the Andes (Andet), the Philippines (Filipinet), etc. In English they take the definite article the, plus the regular plural ending -s. In Albanian, they only take the respective plural suffix.

d) Nouns indicating things made of a substance, garbage, amounts of money and bunches of money (Agalliu et al., 2002, p.105) - bran (krundet), pasta (pastat), glassware (qelqurinat), plantings (të mbjellat), harvest (të korrat), incomes (të ardhurat), leftovers (të mbeturat), etc.

In Albanian, these nouns are used only in the plural number, but in English most of them are not. E.g. bran, pasta and glassware are uncountable nouns therefore, they do not have plural forms, whereas income, leftover, planting and harvest are countable nouns, and as such, they have singular and plural forms. Albanian includes in this group certain nouns such as bakëret, argjendet, të lashtat, that in English are referred to as copper goods, silver decorations, crops (Newmark \& Hubbard \& Prifti, 1976, p. 149), as well as

the noun të hollat (money) whose counterpart in English money is an uncountable noun, and it has only the singular form.

e) There are also a few nouns in Albanian that belong to this group but their English counterparts do not: gjepurat (nonsense), lajkat (flatteries) tekat (whims), të palarat (dirty linens), shtojzovallet (sylphs).

\section{Collective nouns in English and Albanian}

English and Albanian show substantial differences in regard to collective nouns. In English, collective nouns are defined as nouns indicating a group of people, animals, things, institutions: family, government, army, police, audience, class, staff, committee, crowd, jury, orchestra, team, staff, crew, flock, herd, swarm, etc.

Most of the collective nouns in English are countable nouns, and may be used in the singular and plural number, may take singular and plural verbs and numerals as well. E.g.

team (ekip)-teams (ekipe) one team (një ekip)-two teams (dy ekipe)

Our national team has finally managed to win the gold medal in this championship.

A small number of collective nouns may be used only in the singular, but they may take either a singular or a plural verb: youth, gentry, nobility, clergy. E.g. The youth of my town has/have organized the festival of grapes. 
There is also a small group of collective nouns that may be used only in the singular, but they are used only with a plural verb: people, police, cattle, poultry, vermin. E.g. People work hard to achieve their goals.

In English, mainly in British English, collective nouns are treated as plural when the focus is on the group as individuals rather than as a single entity (Greenbaum, 1996, p.104). E.g.

Lynn's family have gathered a lot of money to help their ill friend.

In Albanian, on the other hand, collective nouns indicate an entirety of persons, animals, and things of one kind in the form of the singular number, and they may not be used with cardinal numbers (Agalliu, et al., 2002, p. 85)

E.g. Rinia jonë është pjesa më e bukur e këtij vendi.

(Our youth is the best part of this country.)

Although Albanian collective nouns should be used with a singular verb, in daily speech they may also take a plural verb.

Collective nouns in Albanian are: djalëri (a goup of boys/boyhood), vajzëri

(a group of girls/girlhood), punëtori (a group of people who work), beqari (a group of bachelors/bachelorhood), miqësi (a group of people bound by friendship/friendship), pleqësi (a group of elderly people), fshatarësi (a group of villagers), gjindje (a group of people/crowd), njerëzim (a group of people/humanity), rruzullim (the whole globe/universe), etc.

As seen in these examples, some of them can be very confusing for foreign speakers of Albanian because of their ambiguity. Furthermore, even though they all represent groups of people, only two of them may be treated as collective nouns in English as well - gjindje and njerëzim, which are in fact synonyms. On the other hand, none of the collective nouns of English such as family-familes (familje-familje), class-classes (klasë-klasa), crowdcrowds (turmë-turma), crew-crews (ekuipazh-ekuipazhe), team-teams (ekipekipe), army-armies (ushtri-ushtri), jury-juries (juri-juri), flock-flocks (tufëtufa), herd-herds (kope-kope), bunch-bunches (grumbull-grumbuj), etc., is a collective noun in Albanian, and this can be easily deduced from their counterparts in brackets, which regardless of their meaning that is the same as that of the nouns in English, may not be treated as collective nouns due to their plural forms, and the fact that they may take numerals. Albanian collective nouns do not have plural forms and they may not take numerals. This is one of the characteristics of the collective nouns of Albanian that confuses not only the foreign students of Albanian, but also the Albanian students of English, because one can easily commit the mistake in identifying the collective nouns in Albanian based on the definition of this type of nouns. Furthermore, nouns such as popull- popuj (people - peoples), tufë-tufa (flock-flocks), fis-fise (tribe-tribes), kope-kope (herd-herds), that 
were treated as collective nouns in different grammar books, are no longer treated as such, precisely because of their plural forms and the cardinal numbers that they may take (Agalliu, et al., 2002, p.86).

\section{Conclusion}

This paper has elaborated the key concepts in regard to the grammatical category of number in English and Albanian, placing emphasis on the differences and similarities between these two languages, and providing examples that constitute sufficient evidence that these languages, in spite of their different structural complexity, share several characteristics, namely, both languages have nouns that have the same stem in the singular and plural number, nouns that form the plural by suffixes, nouns that form the plural by a sound change, nouns that combine a suffix and a sound change to form the plural number, and both languages have nouns that are used only in the singular or only in the plural number. Furthermore, concerning the latter groups of nouns called "singularia tantum" and "pluralia tantum", examples show that in most cases, an English noun and its Albanian counterpart are semantically the same, i.e, that they do not only belong to the same group in the respective languages, but they also have the same meaning.

These simililarities, however, come hand in hand with a range of differences such as the ways English and Albanian treat their nouns in the singular and plural number, their use of articles which is exclusively a feature of English, certain plural forms, their almost complete discrepancy in regard to the group of collective nouns that have almost nothing in common in these languages, except the definition, and their compound nouns that are quite confusing, particularly in Albanian which imposes the rule of writing compound nouns as one word, with few exceptions, therefore, compound nouns written as two words in English are not considered compound nouns in Albanian.

\section{References:}

1. Agalliu, F., Agoni, E., Demiraj, Sh., Dhimo, A., Hysa, E., Lafe, E., \& Likaj, E. (2002). Gramatika e Gjuhës Shqipe: Morfologjia (Vëllimi I). Tiranë: Akademia e Shkencave e Shqipërisë \& Instituti i Gjuhësisë dhe Letërsisë.

2. Bache, C. \& Davidsen-Nielsen, N. (1997). Mastering English: An Advanced Grammar for Non-native and Native Speakers. Berlin: Mouton de Gruyter.

3. Baskervill, W. M. \& Sewell, J.W. (2004). An English Grammar. Project Gutemmberg. 
4. Çabej, E. (1987). Studime Gjuhësore III (Botim i dytë). Prishtinë: Rilindja.

5. Greenbaum, S. \& Nelson, G. (2009). An Introduction to English Grammar. London: Routledge.

6. Greenbaum, S. (1996). The Oxford English Grammar. New York , NY: Oxford University Press.

7. Greenbaum, S. \& Quirk, R. (1990). A Student's Grammar of the English Language. London: Longman.

8. Huddleston, R. \& Pullum, G. K. (2002). The Cambridge Grammar of the English Language. Cambridge University Press.

9. Kabashi, J. (2000). English Grammar: Morphology. Prishtina: University of Prishtina.

10. Karlovcan, V. (1989). A Survey of English Grammar. Zagreb: Nakladni Zavod Matice Hrvatske.

11. Kostallari A. (1972). Studime mbi leksikun dhe mbi formimin e fjalëve në gjuhën shqipe (Vëllimi I).Tiranë: Universiteti i Tiranës.

12. Nesfield, J. C. (2016). Manual of English Grammar and Composition. London: Forgotten Books.

13. Newmark, L.\& Hubbard, P. \& Prifti, P. (1982). Standard Albanian: A Reference Grammar for Students. Stanford, CA: Stanford University Press.

14. Rumjanceva, L. \& Kalniòa, B. (2003). English Grammar: Morphology (Volume I). Daugavpils: Saule

15. Trask, L. R. (2007). Language and Linguistics: The Key Concepts ( $2^{\text {nd }}$ ed.). New York, NY: Routledge.

16. Veselaj, N. (2015). Shumësi dhe shquarsia e emrave në shqipen standarde

17. (konstatime, diskutime, propozime). Prishtinë: Era. 